\title{
What is accounting? The "being" and "be-ings" of the accounting phenomenon and its critical appreciation
}

The article DOI: https://doi.org/10.1108/AAAJ-08-2017-3097

Forthcoming in 'Accounting, Auditing \& Accountability Journal'

Accepted $10^{\text {th }}$ January, 2019

\author{
Nihel Chabrak \\ United Arab Emirates University \\ College of Business \& Economics \\ Accounting Department \\ nihel.chabrak@uaeu.ac.ae
}

Jim Haslam

University of Sheffield

Helen Oakes

University of Keele

Acknowledgements:

The authors would like to acknowledge the valuable feedback received from Glen Lehman, Lee Parker, Werner Erhard, philosophy department seminars of UAEU, 2011, 2016, attendees of a research seminar at the University of South Australia, 2010, participants to the Alternative Accounts Conference, Ottawa, 2016, and finally the anonymous reviewers of AAAJ. 


\title{
What is accounting? The "being" and "be-ings" of the
}

\section{accounting phenomenon and its critical appreciation}

\begin{abstract}
The paper reflects a critical perspective drawing from phenomenology, especially informed by a reading of Heidegger, to enhance and extend appreciation of the need to question accounting's meaning or delineation and how research might be undertaken into the accounting phenomenon and related areas. To illustrate and clarify argumentation in terms of accounting mobilization and the domain of accounting research, the mainstream and strongly positivistic accounting perspective adopted in the U.S. is critically assessed. At the same time, we elaborate how much of interpretive research (including much of that labelled critical) is also lacking in terms of the perspective articulated here. The paper stresses the case for questioning the taken-for-granted and conventional. It promotes reflexivity, cautious pragmatism, attentiveness to the value of the existing, responsibility to difference and otherness and openness to new possibilities as part of a deeper critical orientation.
\end{abstract}




\section{WHAT IS ACCOUNTING? THE "BEING" AND "BE-INGS" OF THE ACCOUNTING PHENOMENON AND ITS CRITICAL APPRECIATION}

"[Phenomenology] is as painstaking as the works of Balzac, Proust, Valéry or Cézanne - by reason of the same kind of attentiveness and wonder, the same demand for awareness, the same will to seize the meaning of the world or of history as that meaning comes into being."

(Maurice Merleau-Ponty, 1999, Foreword, p.XVI)

\section{INTRODUCTION}

Buddhist philosophy has compared the perspectives and opinions of an age, historically laid down and shored up sediment-like, to a full cup of tea: people have to empty the cup, as it were, to see things anew or differently, to appreciate the light of wisdom. How, indeed, can new ideas emerge if your mind is full of the power of conventions, effectively translated into certainties of being and taken-for-granted? How can you make your life a journey if no room is left for what experience and new ways of seeing can bring to you? To put it in terms derived from Heidegger, how can you understand "being", if you are confined in a narrow appreciation of it, one "be-ing"? If we cannot totally break from the burden of tradition - and, indeed, we constantly risk being consumed by ways of seeing that might be considered a kind of clutter of the conventional and taken-for-granted - we should preserve the faculty of questioning, to keep open the possibility of going beyond conventions, the taken-for-granted, developed prejudices and the weight of tradition. Following a reading of Heidegger, appreciation of our contingent and situated state and trajectory can encourage us to question and perhaps rework words, concepts and constructs.

Such reflections resonate across the variety of discursive and interconnected arenas in which accounting is a focal phenomenon, whether academic, professional, policy-making, organizational or every-day. In this paper, we develop critical appreciation via two focuses. To 
build and clarify our argumentation, we give attention to the dominant envisioning of accounting in mainstream, strongly positivistic U.S. accounting research. If this is a welltrodden focus, it is very much apposite here. By focusing mainly on the dominant envisioning of accounting in U.S. accounting research through our particular critical lens, we are able to delineate key aspects of our particular contribution in terms of indicating the constrained nature of much accounting research enquiry in contrast with the approach articulated here where there is a constant challenging of the very concepts of the research in the context of driven and reflexive research activity. At the same time, we reflect an awareness of and elaborate the relevance of our problematizing to accounting practices and ideas (including accounting education) more generally. In this regard, we elaborate here on apparent deficiencies in some interpretive and critical accounting research. We draw particularly in the paper upon a reading of Heidegger in developing our critical appreciation, while we enhance argumentation by referring to key influences on Heidegger (notably Husserl) and those for whom Heidegger was a major influence (such as Gadamer and Merleau-Ponty). ${ }^{1}$

\section{The structure of our paper}

The paper is structured as follows. We elaborate a critique of the mainstream positivist research. And we also give substantive attention to related apparent deficiencies in some interpretive and critical research. While prior critique of the mainstream positivist research, which has often been articulated in relation to methodological issues, has noted the

\footnotetext{
${ }^{1}$ Heidegger is a key thinker in the history of post-structuralist and postmodern thought as well asbeing highly influential for twentieth century philosophy more generally including phenomenology, existentialism, hermeneutics and pragmatism (Guignon, 1999 ; see Kolb, 1986). We should however acknowledge, as most commentators do, the problematic character of his political associations, even if these be seen in terms of the like of realpolitik or naïveté (Heidegger himself referred to his stupidity in relation thereto) (see Kolb, 1991). Our reading and usage of Heidegger's texts here is consistent with gaining insights for a critical perspective concerned to enhance general social progress and well-being and in this regard has affinity with texts such as White (1991) and Kompridis (1994, 2006a,b). We see Heidegger being concerned to open up thought, uncovering and un-concealing possibilities (Mulhall, 2005), while also having significant insights into the responsibility to otherness (White, 1991).
} 
mainstream's problematic impact on ways of seeing (see Chua, 1986b), this section emphasizes that a more reflexive approach to accounting and accounting delineation is called for. We also bring out how some interpretive approaches (including some labelled critical) share with mainstream approaches problems in terms of suffering from the clutter of the cup of tea whereby key questions are displaced: What is accounting? What might it be? What role does it and can it play in society, in our world, today? In the displacement of these basic questions there may all too often be an effective acceptance of taken-for-granted and dominant conceptions of the accounting phenomenon. And we see in the mainstream research but also in some interpretive research a key displacement of the researcher.

We develop our position through mobilising insights from Heidegger to challenge the dominance of the narrow and problematic mainstream research and move towards new ways of seeing accounting and its role and reviving the researcher's role in research. If accounting can better counter social injustice and environmental degradation and build social and environmental well-being it is important and we need a new way of seeing it. We should problematize the mind-set of accounting as narrow technical control but at the same time see the valuable in current practices. And we need to be responsible to the other.

We go on to extend our critical appreciation, again drawing on a reading of Heidegger, seeking to overcome the issues highlighted and promote new ways forward through a suspension of prejudices. This is with a view to facilitating authentic encounters in the process of theory development. It entails the promotion of a disruptive kind of truth. 
In concluding, we reflect on implications for accounting and accountability research (and beyond) and highlight our particular contribution. We articulate the importance of our reading of Heidegger in terms of re-imagining and engaging with as well as researching accounting.

\section{KEY DISPLACEMENT OF THE RESEARCHER IN ACCOUNTING RESEARCH}

One dimension that may be referenced in categorising research (see Laughlin, 1995) is the degree of prior theorisation. A relatively closed, tightly defined, theoretical position confines the researcher to a way of seeing the phenomenon. A relatively open, loosely defined, perspective encourages greater reliance on the perceptual powers of the researcher as observer (and, in the double hermeneutic, through the perceptual powers of the observed). Yet both these approaches in practice can sometimes appear to share the assumption that the observer is largely irrelevant in the research process in that 'facts' are seen to emerge by themselves (Laughlin, 1995). Classical science approaches, where research projects are built upon a realist ontology and positivist epistemology, haunt accounting research in this regard (Tinker et al., 1981; Manicas, 1993; Clarke et al., 1999). While considering reality as socially constructed, some interpretive researchers appear to call paradoxically for minimal prompting or predisposition - one wonders at times if they are here being rhetorical, trying to match the rhetoric of more positivistic research (see Gallhofer and Haslam, 2017). Interpretive researchers sometimes appear to want to input into their research analytical categories and invariant properties that ostensibly facilitate empirical testing and argumentation that can be tested in terms of falsifiability. They thus move somewhat away from that differentiating them from the more positivistic researchers, potentially displacing original and legitimate work. 
Interpretive researchers in reflecting on their traditions have acknowledged such points. Ahrens et al. (2008) strongly reflect our argumentation in expressing concern about a lack of an independent intellectual identity for what they term 'curiosity-oriented' research. Further, for Parker (2008), there is the danger that when interpretive researchers label themselves 'alternative' they at the same time reify the centrality of a functionalist ideology that typically deploys an economistic quantification. One can add that when some interpretive researchers describe or label their research as 'exploratory' they undersell its depth and richness and illustrate their lack of identity. And, in their vagueness, they again risk perpetuating a doxic relationship to positivism's metaphors of 'science'.

Today, then, dominant research traditions sometimes appear to substantially distance the researcher from the object to be investigated. This is clear in the artificiality of the positivist approach. But while positivists claim to get to the phenomenon through correspondence, interpretive research also sometimes appears to claim that phenomena can be mystically appropriated through analytical categories. Beyond the sterility of this methodological debate, we seek the researcher's emancipation from barriers to understanding so that she can more legitimately gain greater proximity or come closer to the phenomenon, to bring her attention to what Parker (2008) terms the 'main game', 'facts' not besieged by 'artefacts'. ${ }^{2}$ The researcher cannot resign or be displaced from the research process: meaning emerges only as consciousness is drawn to the focus in research; the phenomenon never shows itself. Research is driven activity (Bernstein, 1976).

\footnotetext{
${ }^{2}$ Again, we emphasize the agreement of Parker (2008), a leading interpretive researcher, with our argumentation here. More generally, we are not denying that many interpretive researchers withhold extreme binary-form judgements and advance many of the orientations we espouse here, including being influenced by phenomenology.
} 
With a phenomenon such as accounting, the driven nature of the activity goes through to the basic questions about what accounting and its role is or might be. Accounting may be thought of as having an 'infinite' character, which may be articulated roughly in terms of onion-like layers: a manifestation is only a part or a particularity (see Gallhofer et al., 2015). To put it in terms drawn from Heidegger we can think of accounting as 'being' and 'be-ings'. As being, accounting is the totality of its possibilities that yields the possibility of a being of accounting reflecting or expressing an authentic way of existing (the goal that we strive towards). Be-ings are particular instances or manifestations of the 'being'. A 'being' in its particular manifestations may be variously displaced, deferred, hidden and held back, entailing the deprivileging of some possible 'be-ings'. The role of the researcher includes going beyond these manifestations. This implies that traditions be constantly challenged and not ossified. The researcher should not be subjugated by the "phallogocentrism" of dominant theories or the fantasy of a "superior" or "in-touch-with-the-tastes-of-the-times, haute couture" theory, even if it enlists an army of allies (Arrington, 2004). Rorty refers here to the value of 'edifying research...[that]...is...abnormal, to take us out of ourselves by the power of strangeness, to aid us in becoming new beings' (cited in Hines, 1991, p. 328). In the critique of positivist accounting research, but also in other research, these points have been neglected and key questions of accounting have been displaced.

How can the researcher, 'being there' (reflecting Heidegger's phenomenology of Dasein), not succumb to the fallacy of remaining shackled by particular 'be-ings', and instead 'being outhere' (Erhard et al., 2015) embark on the journey of endless moves that better realise the potential of 'being'? We elaborate and turn to this in the next section. 


\section{THE “BEING” (DAS SEIN), “BE-INGS” (DAS SEIENDE) AND THE ROLE OF DASEIN IN ACOUNTING RESEARCH}

Heidegger's Sein und Zeit (1986) can be read as suggesting a key insight: in recognizing and coming to an understanding of a particular "thing" we do not exhaust the possibilities of that "thing". There are always other possibilities in 'being' and in 'be-ings'. This is consistent with a concern to question or challenge current delineations of phenomena or with openness to such questioning.

\section{"Being" and "Be-ings"}

For Heidegger (1986), what we understand in language is predicated on prior assumptions understood in a network of "driven activity" that stems from "being-in-the-world": so, phenomena are in effect understood in a particular way reflecting situatedness. However, in our un-reflexive devotion to the conceptual world (Erhard et al. 2015), we are assailed by a "mood" that makes it easier to accept things as they appear or as we know them because others have said so. To "exist" authentically, while being involved in "driven activity", we should turn from that "mood" so as to penetrate the phenomenon. Heidegger stresses the need to project ourselves onto possibilities that may be hidden. Being-in-the-world may thus be an arrow of projection towards a new possibility, which opens up the world. Heidegger describes here a necessary superimposition between being interested in one's own future (existence) and being directed towards the world (driven activity).

It is crucial to here appreciate that an underdeveloped understanding of 'being' will be lacking in terms of its proffering guidance in everyday contexts: it will insufficiently comprehend the extent of obscurity and in-determination in our understanding. Yet, for Heidegger, 
presupposing 'being' implicates an anticipatory glimpse of 'being' - the possibility of a better way of seeing is integral to the philosophy. And 'be-ings' are provisionally articulated in relation to the 'being': there is a struggle here, partly since prejudices that are intermingled in current understandings veil the sources of dominant thinking and stand as an obstacle to new possibilities and a better articulation with 'being' (Heidegger, 1986). As will be explained in the next section, the way this tension is managed is what distinguishes the authentic and competent from the falling Dasein.

\section{The "being" and "be-ings" of accounting}

A reading of this in relation to our focal phenomenon indicates a struggle today in terms of different 'be-ings' of accounting (for instance in terms of content and form) and different envisaged roles for these accountings (including efforts to build transparency for democratic processes). This is actually and potentially. A better accounting, and articulation thereof, may here be envisioned.

If we take what may be seen as an accounting that reflects professional and corporate accounting practice - often understood summarily (and somewhat crudely) as 'conventional' accounting - we find differing appreciations of its character and different roles ascribed to it or envisaged for it. Accounting may, for instance, be understood as a financial representation of the stocks and flows of an organisation and as at least potentially a neutral technical phenomenon that faithfully represents those flows. Its role may be seen as providing useful information for economic decisions (Solomons, 1991a,b). Gallhofer and Haslam (2016) locate positive dimensions of conventional accountings and indicate their mutability in relation to contextual dynamics. Of course, this is also a theorising that appreciates the negative. The need to appreciate the ambivalent character of all accounting actualities and prescriptions 
(including the more 'conventional', see Gallhofer et al., 2015) also encompasses a need to articulate negative dimensions that indeed substantively dominate in conventional practices and visions.

Researchers should question all dimensions of the dominant be-ing to open up to new be-ings of accounting. For instance, Merino (1993) points out that the calculation of financial accounting profit, whether transformed by adjustments to better reflect principles of financial economics or not, can be problematized as a measure of business economic success because prices are not natural but administered in a context where competitive forces are somewhat inoperable. For instance, the types of capital provided by stakeholders without marketable property rights, such as human capital, are not accounted for. It follows that their interrelations are excluded from the price system, which limits the power through legitimacy of accounting profits calculated as measurements of economic performance.

Many researchers have argued, focusing mainly on conventional varieties of accounting, that accounting does not mirror 'what is' but influences, reifies and legitimizes social reality (Tinker, 1980, 1985, 1988, 1991, 1999; Tinker et al., 1982; Neimark and Tinker, 1986; Chua, 1986b; Hines, 1988, 1991). Accounting has been interpreted as a powerful myth or symbol compliant in the construction of social reality (Covaleski and Dirsmith, 1990; Everett, 2002). It has been conceived of as a discourse sustaining, reproducing or transforming wider institutional and social structures (Cooper and Sherer, 1984; Hopwood, 2000; Cooper, 2002; Shearer, 2002). It may help support an individualistic economic contractual approach to social life. It can thus become an instrument in a context of globalisation to enliven a race-to-the-bottom, to increase profits for capital, to allow extractive business logics, to demand lower social obligations and to tolerate environmental degradation, and indeed to diminish well-being. 
Sikka (2008) argues that (conventional) accounting can promote the corporate State and its destructive culture while creating a reality where a particular variant of capitalism (a particular financial capitalism) is the supported configuration of the social order.

Other be-ings of accounting with variety in terms of content and form as well as character and role, beyond narrowly conceived conventional accountings, are envisaged in accounting research (and in various ways in practice). This includes accounting going beyond the calculative (especially in the sense of quantitative) and the financial. For Lavoie (1987), accounting has a non-calculative dialogical aspect. In this regard, for instance, accounting has the potential to be 'shaped' to provide a 'point of view' about, e.g., profit. As a narrative (and indeed as calculation, including alternative calculation), accounting can take many possible directions in the public spheres of modern communities. Accounting can inform about and make visible a wide range of matters relevant to well-being and thus contribute and make a difference to the community (Parker, 2008). This is not only in terms of varieties of social and environmental accounting for a wide range of entities or focuses but also through the espousal of new strategies such as ecological holism, performative parody and democratic reflexivity (Everett, 2004). For Birkin (1996), corporate environmental accounting can re-present people and their concerns and re-establish the ethical relation to land, distorted by modernity. Accountings can be mobilised and used by civil society organizations to help create a public sphere to inform citizens about how human beings, corporations, organizations and nations intervene in the natural and social environment and involve citizens in an endeavour for social betterment (Gallhofer and Haslam, 2003; Gallhofer et al., 2006; Spence, 2009; Lehman, 2010; Gallhofer et al., 2015). Accounting can create and shape new spaces and conversational domains (Erhard et al., 2015) in public debate, question the harmful consequences of 
modernity as it has manifested and suggest new ways of organizing society, e.g. in line with more compassionate values. ${ }^{3}$

The various accountings so far encountered as actual and potential phenomena in academic discourse have parallels in various accounting mobilizations in other arenas. Our concern, following on from the above, is to uncover and appreciate these be-ings of accounting and to critically explore them. We should be concerned to critically appreciate and challenge all these phenomena. While appreciating moves to critique conventional accounting and articulate more critical and alternative accountings, we also seek to address senses in which many of the diverse accountings so far manifest in theory and practice suffer a lack in terms of insights from a reading of Heidegger.

\section{The falling Dasein}

For Heidegger, that which is the better in conceiving and realising new or emergent 'be-ings' is the remarkable, competent and authentic Dasein, the 'entity which each of us is himself and which includes inquiring as one of the possibilities of its Being' (Heidegger, 1986, p.31). If Dasein falls one loses what makes it remarkable, the faculty of questioning: the falling Dasein loses this faculty and effectively just accepts in that it becomes no longer itself falling, as it were, into the trap of 'one thinks such and such'. In its decay, Dasein can lapse into alienation and miss its own being, fleeing from inspirational mystery and wonder to take refuge in continuing taken-for-granted notions of everyday reality. Dasein can thus come to be flitting

\footnotetext{
${ }^{3}$ In some respects new ways of seeing may involve the re-appropriating of old ways: e.g., among many possibilities from the past, Bentham's expansive view that accounting functions as a branch of ethical practice (Gallhofer and Haslam, 2003) or the ostensible role of accountings in ancient societies (see Gray et al., 1996): for instance, in ancient Babylon, a scribe's duties were to record and audit transactions to ensure compliance with the code of King Hammurabi, reflecting an objective of unifying the Babylonians in a just society.
} 
from one banal everyday object to another. Absorbed by particular narrow utilitarian concerns in a set of "worldly" meanings, in an unmoved familiarity, Dasein can become submerged into a thinking "as people think". Shifted from anxiety over what it is to "exist", to find its own authentic path, it wallows in a horizon of imposed understanding whose existence it does not suspect given the loss of the faculty of inquiring. Under a silent and reassuring dictatorship of "what people think", of parroting others, Dasein is detached from its authentic singularity and falls into casualness. It may not perceive that its "be-ing" is only one chosen possibility that can displace other possibilities; it may think it can no longer escape (Heidegger, 1986).

For Heidegger (1986), the interest of Dasein is confined by the power of tradition. Tradition becomes very inaccessible, it seeks to claim self-evidence by blocking our vision of the sources of its categories and concepts and making us suppose that we do not even have to understand the necessity of going back to these sources.

\section{The falling Dasein in accounting research}

Much strongly positivistic accounting research, especially that reflective of conventional economic logic, can be analysed in the above terms. ${ }^{4}$ One can appreciate how a rhetoric of tradition is at play in the constitution of ideological effectiveness for such research. Reference to its sources, especially its narrative sources, have been erased so that its categories and concepts seem natural and ahistorical even while they reflect a specific interpretation of the social order - and contribute to maintaining it (Tinker et al., 1982). Mainstream positivistic

\footnotetext{
${ }^{4}$ The implication of our argumentation, we should stress, is not that there is no value in seeking to pursue the conventional scientific method. Heidegger actually acknowledges the value of this for certain purposes (see also Chua, 1986b). We are seeking to promote more openness to interpretive approaches that open up possibilities to study a wide range of under-researched areas vital to accounting and society.
} 
research is often disseminated by dint of the force of its dissimulation. So many strongly positivistic accounting researchers fail to properly perceive their confinement within categories and concepts of the ideology of neoclassical economics (Arrington and Schweiker, 1992; Gray, 1992; Williams, 2004, 2009; Ravenscroft and Williams, 2009; Lehman, 2010). Researchers here are somewhat unaware of the blinkered nature of their approach, bounded by the tenets of their theoretical framing. From the perspective of this framing, how, for instance, can accounting be blamed for not realising its potential beyond this framing?

Under the hegemony of neoclassical economics and its particular individualistic approach, in much of such research various dimensions of the world are overlooked: the narrowness of and lack in the particular individualistic materialism; the exploitation of human and natural capitals by financial capital; of the world's ecology by unchecked production; of women by men; of poor by rich; of indigenous by colonisers; of nation state democracies and autonomies by supra-national forces. Accounting too is simply accepted in its conventional manifestation. Demystifying these dimensions can scarcely be conceptualized from this hegemonic perspective. The affiliation of accounting to such demystification and more positively to a more holistic notion of emancipatory social betterment (Gallhofer and Haslam, 2017) requires what Ravenscroft and Williams (2009) term a: "conceptual shift in the focus, assumptions, and discursive practices used to characterize, explain, and speak about accounting practice" (pp. 774-5). Narrowing accounting and its role to one particular possibility of its 'being', notably an ostensibly conventional accounting in the current context, is damaging in overshadowing and delimiting how accounting can affect other spheres of human life (Shearer, 2002).

Some critical and interpretive accounting writers in analysing conventional accounting have worried about the erasure of alterity so that any subject can act on a world of objects (see 
Birkin, 1996; Lehman, 1999; Shearer, 2002; Everett, 2002). Such work indicates that when the other is denied and objectified through conventional accounting and related processes it appears only as an object to at least potentially satisfy the subject's desires. A particular concern here has been to bring out how responsibility towards the 'other' is problematically achieved in the pursuit of sovereign private interest, not enhancing responsiveness to the community. Shearer (2002, p. 553) sees this as bringing about a situation whereby: “...the lives of people, the existence of non-human life forms, the integrity of ecosystems, and the sovereignty of nations all are made subservient to the instrumental pursuit of profit or productive growth". Conventional accounting is thus seen in the image of an instrument of "homo economicus", pursuing that objectified for wealth "usurpation", driven by a narrow and short-term self-interest, accepting monetary valuations failing to respond to reasonable standards of morality (see Tinker, 1985). These concerns about instrumentalist pursuits echo Heidegger's concern (e.g. Heidegger, 1986) about the way humans have sought to secure power over nature (broadly conceived): extracting from nature and transforming nature into an object. Yet, some critical and interpretive accounting writers scarcely redress the control orientation and presumptions of their own accounting advocacies, stopping short of Heidegger's more general commitment to a loving and attentive appreciation, a deep awareness beyond technical control (subter).

Parker (2008) effectively highlights the falling of accounting researchers in their sticking to tradition. In accounting, argues Parker (2008), there is a veritable tsunami of narrow and narrowing research with an absence on the part of its proponents of much self-critique or selfdoubt but tunnel vision towards assembly of pseudo-facts or "artefacts" (see Parker \& Roffey, 1997). The researchers employ categories they inherited in an unreflective way without questioning the sources. Subjugated by tradition, researchers are in effect unaware of the 
possibility of better views through different lenses (Tinker, 1999). Beyond refinement and consolidation of their perspective, they by-pass the new and take few risks (Hopper et al., 2001; Parker, 2001). For Gaffikin (2009), accounting research is largely in an intellectual vacuum because it has ignored the crucial need for self-reflection.

In the global context, the dominant approaches to theory development in accounting in effect have failed to substantively meet the lived experiences of the empirical realm (Chua, 1986a). For Parker and Roffey (1997), we need praxis in research that does not deteriorate into theoretical esotericism and create a reality of accounting carried on for its own sake and distant from the practical world (see Scapens, 2008; Gaffikin, 2009).

With regard to many varieties of conventional accounting, Macintosh and Shearer (2000) have argued that accounting circulates like a simulacrum in a hyperreality - a self-referential model losing touch with a meaningful notion of reality. By epitomizing accounting as a triumph of true information, the falling researchers (supra) contribute to a project legitimizing the sociopolitical order, which is presented as self-evident and natural while in reality it is pre-ordained, contingent and controversial (Cooper, 1980; Tinker, 1988; Tinker and Neimark, 1987; Arrington and Francis, 1989, 1993; Baker and Bettner, 1997; Chwastiak, 1999). The conventional accounting promoted here predominantly serves narrow interests detrimental to social justice and well-being (Williams, 2002; Tinker and Carter, 2003). Such is the dominance of conventional accounting in the discourse of practice that alternatives are often constructed so as to reflect the convention rather than reflect their potential in a meaningful difference. Spence (2009), in this regard, argues that many corporate social accounting failures are rooted in close ties to the economic base of society and to neoclassical reasoning. 
Spence (2009) emphasizes how social and environmental accounting research has expanded not so much because of the informational value of social and environmental accounting for communities and vis-à-vis a more holistic notion of betterment but more because it is seen as a new avenue for bolstering shareholder return - and substantively re-enforcing business-asusual. Thus, for Spence (2009), corporate social accounting (in its dominant form, as distinct from the radical variants of counter accounting) is counter-productive to the project of enhanced democracy, rather playing a role that is counter-progressive and supportive of the established order. It closes off potential debate and instead of substantively debunking corporate rhetoric it actually maintains ideological autonomy for business and markets. Gallhofer and Haslam (2017) retain much of the substance of such argumentation but consistent with a less dichotomous and monochromatic reasoning as they see progressive actualities and potentialities in all accountings.

We emphasize here that 'social accounting' alternatives that have manifested in theory and practice that have sought to go beyond the conventional (towards more radical variants) also typically share with the conventional in a lack from a Heideggerian perspective. In a deeper sense, many of these alternative accountings are driven by a calculative thinking and scarcely exhibit much caution about such an orientation. Even less do they reflect the Heideggerian call to be attentive to the existing and not always take it as given that it has to be controlled for our purposes, a notion that in Heidegger reflects a heightened responsibility to otherness.

Gallhofer et al. (2015) and Gallhofer and Haslam (2017) only implicitly acknowledge the Heideggerian critique in this regard. The new pragmatist post-Marxist thinking of Gallhofer et al. (2015) and Gallhofer and Haslam (2017) indicates the ambivalences, ambiguities and complexities of all accountings, from conventional to social/environmental and to counter 
accounting in a nuanced analysis that reflects a continuum thinking emphasizing relative rather than absolute difference. Substantively, their analysis points to various negative (as well as positive) features of such accountings and in this sense is consistent with much of the above critique. In Gallhofer et al. (2015) and Gallhofer and Haslam (2017), while a cautious pragmatism and a concern to respect the other is given emphasis, there is understatement of the Heideggerian commitment to the need to be aware of and attend to the value of the existing and the other and to problematize in this sense the basic control orientation.

Striving to bracket the notion of control as an at least potentially narrow and excessive practice may be seen in terms of engendering a control orientation that is better, deeper and more expansive: more holistic; more pragmatic. Thus, we can turn more towards seeing value in preserving what we have or some aspect of it. Heideggerian perspectives here are sometimes articulated in terms of love, wonder, attentiveness and awareness (Heidegger, 1977, see also Merleau-Ponty, 1999). If some may find this to acknowledge too many positives in conservative positions, Heidegger's way of seeing is consistent with a deep responsibility to otherness and the more cautious pragmatism that is evident in the more recent critical turns in post-structuralist, postmodern and post-Marxist literature, critical turns that have been understood to render critical work deeper and more expansive (see Laclau and Mouffe, 1987, 2001; Butler et al., 2000; Gallhofer and Haslam, 2003, 2016; Gallhofer et al., 2015). In this regard, Okrent (1988) and Rorty (1991) articulate senses in which Heidegger may be understood as a (reluctant) pragmatist philosopher (see Kolb, 1991).

\section{Dasein and "disobstruction"}

Going beyond the basic control orientation and beyond the conventional, going back to the point of origin or departure that led to the conventional, is a challenge. Dasein may be 
considered alienated by its confinement in a particular problematic 'be-ing'. Yet anxiety can here be heightened in the realisation of one's irreducibly different singularity, something that can serve the estranged Dasein in facilitating its opening up to alternative, radical perspectives (Heidegger, 1986; Laclau and Mouffe, 1991; Derrida, 1995). And the sense that nothingness is the foundation of its "being" as "being-towards-death" is what helps Dasein escape from the casualness that seems to suit it so well. Awareness can engender 'thinking investigation' and problematisation reflecting Dasein's competent enactment of 'driven activity': this involves questioning knowledge and 'the rendering of freshness to ossified tradition, and the stripping off of the coatings it has accumulated over time' (Heidegger, 1986, p. 48).

Heidegger (1986) elaborates an aspect of this in terms of 'disobstruction'. Instead of inflating knowledge simply through the continuing of tradition, it is important to make progress on problems that have long remained impenetrable: science should subject its basic concepts, which have been virtually consigned to oblivion, to a radical overhaul, and shake-up the relationship it entertains with objects of investigation; there is a need to 'step backwards' (disobstruction) and to go beyond a basis for starting out, established for deduction, that amounts to an undemonstrated principle (Heidegger, 1986). This is consistent with returning to consideration of 'being' and 'be-ings' beyond narrow existing confines (supra).

For Heidegger, the world of 'be-ing' should be transcended by, and be informed and guided by, "being" (as opened up through questioning). In accounting, this involves appreciation of accounting-in-general, that which is not set out in front of us, but which is in the background, that which is on the horizon, the encompassing, basic, notion that yields insights for the reworking of 'be-ings' (Heidegger, 1958, 1962, 1992). This may be understood as a return to ontology, in Heideggerian terms the phenomenology of Dasein (Heidegger, 1986). 


\section{PHENOMENOLOGY AND “BEING”}

In Heidegger, phenomenology, embracing a concern to be open to learning from the object, is an ontological turn consistent with going back to the point of origin (supra).

[Phenomenology expresses a]...maxim which can be formulated as 'To the things themselves!' It is opposed to all free-floating constructions and accidental findings; it is opposed to taking over any conceptions which only seem to have been demonstrated; it is opposed to those pseudo-questions which parade themselves as 'problems', often for generations at a time. Yet this maxim, one may rejoin, is abundantly self-evident, and it expresses, moreover, the underlying principle of any scientific knowledge whatsoever (Heidegger, 1986, p. 54).

Of course, Heidegger does not mean here that the phenomenon shows itself. The phenomenon is always something veiled but can be better accessed. And the core of what is hidden is that which would disturb the seemingly established and self-evident 'be-ing' or 'beings'. Returning to accounting research, its dominant tendency to a dogmatic acceptance of the 'be-ing' of accounting as conventional and as neutral (unbiased), with a related presumed role, risks naturalizing constructs of economic utility and individualistic economic rationality and rendering taken-for-granted constructions as valid such as those articulating the possibility of an 'efficient' market. Attention needs to be intentionally directed to accounting as a phenomenon in a critical appreciation of 'being'.

\section{Intentionality}


Let us turn to Husserl - of course, a great influence on Heidegger - in exploring this intentional direction. Husserl introduced the concept of intentionality borrowed from the psychologist Franz Brentano (whose lectures he attended in the winter of 1884-5). Intentionality carries consciousness towards its object and in relation to driven activity consciousness seeks to become itself by accepting the other. In phenomenology, a consciousness is fundamentally a consciousness of something. Meanwhile, the object in its original existence is meaningless. When intentionality carries consciousness towards its object, the latter emerges literally as meaning for it. This involves or evokes interaction or conjunction between the subject and object (see Depraz, 1998) that goes beyond the sterile debate between ontological idealism and realism.

Concepts of profit and cost in financial accounting may here illustrate intentionality. Rather than raw materials that financial accounting could describe in a neutral way, these concepts change every time the accounting storyteller narrates them: for instance, what is paid to workers is typically seen as a cost in the capitalistic accounting system but as a profit in the old Yugoslavian socialistic accounting system; taxes paid to the State may be considered like costs in capitalistic accounting and as profits (or surpluses) in the old Soviet system (Richard, 2000). As Shearer (2002) appreciates, we are, in this regard, the stories we tell: by espousing neoclassical economic theory, we actually build conditions for it that expand its applicability or influence towards the whole of human experience; more than that, we transmute the broader spectrum of human motivations into instances of self-interested utility maximization as everything becomes transaction (see James, 2007). "Civility" is here reduced to subordinating questions of justice to questions of private property rights and to markets. Again, the point to emphasize is that the researcher should question any taken-for-granted character of the researched and thus, for instance, suspend the naïve conception of accounting as neutral: or, 
under the silent imperialism of a problematic neo-classical economic reasoning, accounting may hide or otherwise support perverse priorities and values of the financial capitalistic sociopolitical order that contribute to the massive destruction of the social good and nature (see McKernan, 2007). At the same time in and through the discourse one is seeking to appreciate the phenomenon and recognise its positive actualities and potentialities (Gallhofer and Haslam, 2017).

The epoche (bracketing) or suspending of the natural attitude: effort to suspend prejudices in the doing of good research

Husserl (1992) articulates phenomenology as a "contemplating" of the phenomenon in its context, an initial abstaining from explanation. The epoche or suspension of the natural attitude signifies a stopping, interruption or holding back of a naïve attitude to phenomena an attitude that displaces the possibility of going beyond surface appearance and simple explanation - and also the promoting of an attitude to continuously seek to be open to reality beyond the prejudices that one inevitably holds.

To understand a phenomenon, a "displayed hidden" (Heidegger, 1986), it is necessary to show due reverence towards it (Gadamer, 1996). Rather than the locating of phenomena in simple formal models, there should be genuine effort to understand them, and openness to evaluating our opinions on the things on their own terms (Bernstein, 1982). Epoche or suspension consists of putting into brackets judgments, opinions and inherited scientific truth positions. The researcher is always cradled in a tradition, and it would be hypocritical to deny this and hide behind slogans of neutrality and objectivity in the name of science. Some of the 'purer' positivistic researchers in accounting claim "objectivity". This proselytism (Williams, 2009) contributed to make a positivist cult (Chambers, 1993). Yet, knowledge is a construction 
by the researcher (Tinker, 1998, 2001) who cannot be concealed from the process of its production as claimed by the 'pristine' positivists. The researcher is the consciousness directing attention to the world. In doing so, the world becomes meaningful. This does not negate the value of openness to, and reverence towards, a phenomenon. The consciousness can strive to construct an authentic understanding of phenomena by striving to free itself, even in a relative and temporal, even momentary, sense, from the tradition by suspending its prejudices:

What I considered to be my inherited structure of understanding, what I believed I had to carry out in this world, it seemed that I had to place all this in front of me and put it back into movement like an open worksite, awaiting acts (Desanti, 1994, p.20).

The epoche constitutes the root of phenomenological analysis, a critical attitude expressing a reform of understanding (Husserl, 1992), which is a disengagement from the mode of mass belief and the taken-for-granted. The critical attitude for Husserl is the trial of placing the fate of the thing in suspense by learning to be patient and by letting experience emerge. For Husserl (1992), the epoche does not consist of abolishing knowledge, as this negation would be something "non-philosophical". It is rather an act of adjournment to avoid the pitfalls of the natural attitude (Husserl) or the objective thought (Merleau-Ponty), which prevent doubt and understanding. The natural attitude is the placing of the world as the absolute foundation for all truth (Housset, 2000). For Husserl (1998), empiricism (in the sense of Bernstein, 1976) is the first manifestation of the natural attitude. It reflects an absolute belief in the world as the totality of spatio-temporal events and denies for consciousness (the observer) any recognition or sense of personal space. 
Another form of natural attitude is disguised under the spectre of intellectualism or Cartesian reflection (Merleau-Ponty, 1999). It is the a priori reflective analysis that breaks with the world itself and constitutes it by the operation of consciousness. Knowledge construction is here ostensibly undertaken in total disconnection from the world (Merleau-Ponty, 1999). Intellectualism formulates concepts, postulates and theories that are attached usually to a specific vision of the world, and naïvely remains caught up in the illusion that it can explain the world by an arrangement of these concepts. Its explanation evolves towards a possibility always conditioned by current knowledge, and may miss the phenomenon as an "infinite idea". It is "a world-centred reflection, a truth as seen by the prisoner in the cave who prefers the shadows to which he is accustomed and who does not understand that they owe their existence to the light" (Merleau-Ponty, 1999, p.52).

The phenomenology of perception provides an escape from the idealism of intellectualism (rationalism), without falling into the naïve acceptance of the realism of empiricism (positivism) (Merleau-Ponty, 1999). If phenomenology is opposed to the absoluteness of the logic of naturalism, Husserl does not see it as exactly a return to the sceptical relativism (all truth is relative to the judging subject) of historicism attributed to Dilthey:

Naturalists and historicists fight about Weltanschauung, and yet both are at work on different sides to misinterpret ideas as facts and to transform all reality, all life, into an incomprehensible, idealess confusion of 'facts'. The superstition of the fact is common to them all (Husserl, 1998; p.79).

The failure to suspend prejudices is illustrated in the case of mainstream U.S. accounting research by the latter's rigid and rhetorical demarcation of normative accounting from positive 
accounting. The latter is deemed scientific whereas the former is deemed pseudo-scientific. This is a naïve characterization of research that may serve to ideologically buttress the mainstream research in certain contexts (see Chabrak, 2012).

\section{From "Truth" as correspondence towards "Truth" as disruption}

The natural attitude is the illusion of a truth existing outside of (realism/objectivism) or inside the mind (idealism/subjectivism). Phenomenology denounces both these dimensions. It is not concerned with the sterile debate on the subject/object relationship and a dispute between two perspectives characterised by the negation of their opposite. In his work on phenomenology, Husserl (1976) deplores that science and positivism makes men fetishists of facts who rarely ask themselves about the way they look at facts. With intentionality, phenomenology detaches itself from conventional conceptions of philosophy as a theory of knowledge - a conception based on the dual opposition of subject and object (Depraz, 1998). Phenomenology as an ontology advocates breaking with the conception of the world as independent of the mind, and of things that are what they seem to be. In real-life experience, phenomenology seeks for "the unity of a meaning which is prior to any sterile dualism" (Depraz, 1998, p.3). The world takes on a meaning only for consciousness and consciousness only for the world. This implies the advent of a joint world and mind out of the various actions accomplished by being-in-the-world. Consciousness is neither the reflection nor the mirror of the world. Husserl suggests that the world should be comprehended by seeing in it the mark of our own structure. It is a break with the conception of Man as reduced vis-à-vis truth so that truth is only seen as accessed in an unmediated way. It is the consecration of Man as subject because truth cannot be revealed on its own. This is a new way of thinking about the type of otherness of the world, without eliminating it (Housset, 2000). For Bernstein (1982), following Gadamer, the meaning of what we seek to understand is not self-contained, it does not exist 
an sich, a posited object as it is in itself. The meaning is only realized through the happening of understanding.

With reference to accounting, for Hines (1988), prior to our conceptual schemes, there is just a jumble of things: uninteresting because no theory of truth or of knowledge is implied; there is emptiness (McKernan, 2007). The idea of objective reality in this regard becomes problematic and undesirable when it exerts an external pressure on researchers (and beyond) in the guise of a major step towards better coincidence of truth and reality with accounting.

In his paper, McKernan (2007) criticizes Shapiro's (1997) concept of accounting vis-à-vis external reality. Following Searle, Shapiro (1997) argues that some reality exists out there independently, but does not make any epistemological claim about how or how well an observer might come to know or perceive that reality (p. 168). He goes on to argue that accounting does not make the world, it makes a description of it, and some financial reporting models are better than others in describing some features of this external reality. Is it possible to specify convincingly how things are in the world prior to accounting descriptions (McKernan, 2007)? Can the financial reporting model be a separate conceptual scheme supposed to represent an external reality? Rather, is it not just a suburb of the universal scheme, our theorizing of the world, shaped jointly by the world and our interest in the world (Davidson, 1997b; see McKernan, 2007, p. 169)?

The simple idea that is associated with much of the conventional accounting literature about the possible existence of an "optimal", "high quality" standard of accounting that could lead to the best translation of economic reality becomes a myth. As explained by Varela et al. (1991), the enactive paradigm in cognitive science explicitly calls into question the prevalent 
assumption that cognition consists of the representation of a world that is independent of our perceptual and cognitive capacities. The paradigm of "enaction" outlines instead a view of cognition as "embodied action", which situates cognition within the context of evolutionary theory. Indeed, evolution consists not in optimal adaptation but rather in "natural drift". Hence, cognition has no ultimate foundation or ground beyond its history of embodiment: "the key point, then, is that the species brings forth and specifies its own domain of problems to be solved by satisficing; this domain does not exist "out there" in an environment that acts as a landing pad for organisms that somehow drop or parachute into the world. Instead, living beings and their environments stand in relation to each other, through mutual specification or codetermination. Thus, what we describe as environmental regularities [economic reality which researchers strive to reflect through accounting categories] are not external features that have been internalized, as representationalism and adaptationism both assume. Environmental regularities are the result of a conjoint history, a congruence that unfolds from a long history of codetermination, the organism is both the subject and the object of evolution" (Varela et al., 1991, p. 199).

Investigated in the name of representationalism and correspondentism implied by the notion of external reality in Shapiro (McKernan, 2007), the inclusion of stock option compensation in accounts is actually an example of deeply ideological social practice. For Berenson (2004), the use of stock options was the irrational driver of the stock bubble of the late 1990s in the U.S. Ravenscroft and Williams (2009) explain how the FASB adopted SFAS 123R to better reflect the economic consequences of this practice. To increase transparency, the standard requires firms to report the fair value of the options at the grant date. Since these options are not traded on the market, the Black-Scholes or Lattice option pricing models are applied to derive the fair value. The application requires numerous assumptions, including about the functioning of 
markets. For Ravenscroft and Williams (2009), both models emerge from the imaginary world of neoclassical economics: accountants accepted this world so they have the responsibility to make it real. The adoption of the useful information metaphor and the acceptance of its underlying presupposition that financial reporting quality is related to its correspondence to an objective reality overshadow the instrumental role of accounting in naturalizing neoliberalism (Ravenscroft and Williams, 2009). Positive accounting theorists with commitment to neoclassical economics and their predecessors from the Chicago School continue to claim their approach as a disinterested and objective inquiry and as the only rigorous scientific procedure leading to correspondence with mind-independent reality and faithful representation of it. In doing so, they oriented accounting practices presupposing new rationales to sustain the authority of the type of capitalistic order they promote.

Since the "be-ing" of accounting as neutral is correlated to the idea of realism and the notion of "Absolute Truth", which is deeply rooted in the Western tradition, to encourage researchers to conceive accounting practices and institutions differently, it is crucial to shake the traditional conception of "Truth". This can be done by addressing the question of "being". Rorty (1998) argues that the Western rationalistic tradition is a secularized version of the fundamental style of Christian Theology - what Heidegger calls "onto-theology" (Rorty, 1991). As explained by Laughlin (1995), this tradition expands from the dominant Christian underpinning of God's ordering of a rational world waiting to be discovered through rational processes, to the more agnostic position and division between the European rationalists such as Descartes (who had a final recourse to God), Spinoza and Leibniz. These rationalists thought that an absolute description of the world uncontaminated by the experience of any observer was possible through reason. The English empiricists such as Locke, Berkeley and Hume argued that our ideas are the outcome of what comes to us via our senses. The division between the 
two traditions was resolved in one way by Comte's positivism, especially in response to Kant's idealism and its inherent subjectivism. Positivism is a tightly defined rational, deductive process coupled with similarly clear rules on how to observe the empirical world, where subjectivity has no part in its make-up (Laughlin, 1995, p.73). A pristine positivism is rooted in human desire for certainty and a fascination for absolute truth. The idea of absolute truth of reality - as it is in itself - is deeply preoccupying as we explained previously. In the name of this truth, instruments of emancipation, over the course of time, turned into instruments of repression (Rorty, 1998, pp. 76-8).

For Heidegger, truth - or aletheia (un-hiddenness) - is the appearing, un-covering and disclosing of things - as the things that they are - within a horizontal (or surface-level) setting (Malpas, 1992, p.267). ${ }^{5}$ Truth is here the opening-up of the horizon of possibilities, engendering the primacy of phenomenology as critical ontology. It is the revealing of the "being" by the 'concealing' of one "be-ing" from which it comes. It is a complex processual dynamic of understanding:

Truth reflects the dynamic of understanding: we are wrenched from our immersion in a project by the disruption of that project only to submerge once more as the project is reconstituted or a new project arises. Such immersion is itself a concealing of possibilities (Malpas, 1992, p.268).

Only aletheia manifested in opening-up and freeing-up can maintain possibilities for understanding. The articulation of a complex processual dynamic helps to explain Heidegger's claim that Dasein is "equally in truth and in untruth", and that problematisation reflects the

\footnotetext{
${ }^{5}$ In modern everyday Greek, the meaning of the word is similar to truth in modern English. Through a hermeneutics of ancient texts, Heidegger invests it with a richer meaning in his analysis.
} 
competent behaviour of Dasein. Truth is not conceived as correspondence or as the related notion of coherence; rather Truth is something like the idea of the constant process of disruption, in which new possibilities of meaning are revealed/concealed (see Malpas, 1992). For Heidegger (1986), this conception of "Truth" helps to shake off tradition instead of its appropriation (see Kolb, 1986; Krell, 1992, 2006; Ward, 1995; Thomson, 2011). It is consistent with a responsibility to the other.

Truth as disruption has crucial implications for accounting research and indeed the practices and discourse of accounting, for a long time conceived on the basis of truth as correspondence. The first implication is the rejection of "be-ing" neutral (in the sense criticised by Tinker, 1991) in accounting research and practice. The second implication is the need to explore how accounting practice and economic decisions are all embedded in social life. This understanding may help highlight areas of today's accounting that are currently too much in the shadows. The truth as disruption could render voice to what has been silenced because of the hegemony of a certain type of economic thought. According to Cooper et al. (2010), despite living in "the audit society", human rights violations and abuses, unfairness and usurpation continue since accounting's current forms are unable to make them visible. They ignore social imperatives and leave no space for rendering income and wealth inequalities discernible. The break with the dominant theories and the return to phenomenology helps researchers to see how accounting is relatively silent or soundless on these topics. Accounting has currently little to say on how corporate behaviour damages lives and dignity and the social and ecological environment. Accounting is not playing a very useful educative role in raising the awareness of citizens to important social and political issues. A new project of "be-ing" of accounting could open new avenues for researchers and practitioners to study other issues, instead of the body of artefacts and pseudo facts that dominate the current research agenda 
(Chabrak and Gendron, 2015).

The issues elaborated here in relation to phenomenology as ontology from a perspective drawing from Heidegger - and the advances thereby reflected in intentionality, epoche and truth as disruption - have significance not only for the critique of conventional accounting research but also for much interpretive and critical research. In relation to intentionality, some ostensibly anti-positivist researchers appear to be still sublimated by the myth of objectivity in that they are unable to assume intentionality in the production of their research. Consequently, they do not recognize the significance of the act of epoche of their natural attitude in conducting research. They still share the prejudices of the inherited categories of their own research tradition. Also, some critical and interpretive researchers substantively eschew the notion of pursuing truth as disruption and hence underplay the critical possibilities - involving a new way of appreciating consciousness and the otherness of the world.

\section{Articulation in terms of the responsibility to otherness}

The insights can be interpreted in terms of emphasising a heightened sensitivity to otherness, which has particular characteristics in Heidegger (a face-to-face quality, an experience of otherness), that has to be somehow balanced against the politico-ethical responsibility to act. Without this balance or fruitful tension there is a danger of ascribing 'justice' to e.g. political arrangements that are shot through with oppressions, neglect, marginalization, exclusions, suffocation of diversity and disrespect: instead of seeing the pursuit of justice as a ceaseless open-ended, multi-dimensional and complex endeavour (White, 1991). Heidegger here arguably still adds something to postmodern philosophy in seeking a continual reaffirmation of a responsibility to otherness. Heidegger appears to be committed to the idea of experiencing or seeking to experience otherness that allows the other to be in its difference: given the 
contradictory nature of the commitment it implies a kind of balancing or mixing, a state of ambivalence or ambiguity. But this effort, a deepening of learning from facing the world differently, may have positive effects on modern lives: it can embrace fostering otherness beyond tolerating it (White, 1991). Reflexivity should be concerned with responsibility to otherness as should the search for the truth as disruption. In mobilising accounting and in necessarily being concerned to control, we need to at the same time be thus more richly informed and to reflect this.

\section{IMPLICATIONS FOR ACCOUNTING RESEARCH: A SUMMARY}

To mobilize truth as a disruptive endeavour, it is crucial to find mechanisms preventing new discoveries from becoming "sedimented habitus". Heidegger's philosophy of the "being", the "phenomenology of dasein" and truth as "aletheia" indicates how to liberate research from the conventional appreciation or "be-ing" of accounting as neutral but not to take overconfident refuge in any other established "be-ing" at the risk of that becoming another "sedimented habitus".

This paper calls critical accounting researchers to avoid being narrowed in a type of "be-ing" at the risk of not promoting, albeit cautiously and pragmatically, an alternative accounting model and practice. Some critical and interpretive researchers seem to be more devoted to establish the veracity of the theories they cherish rather than being driven by the concern to work on and change the phenomena they explore. Unconsciously, such approaches risk becoming confined in a certain view of the world and wallow in a natural attitude towards it, in a way that is congruent with their more positivistic and conventional rivals. Their contribution which more generally is weakened by offering opponents some means to defeat their project risks becoming just the shoring up of a sedimented habitus. 
To keep on the path towards the "being", "be-ings" beyond already manifest positions should be explored, examined, questioned and transformed. Hence, we should apply systematic doubt any time a new "be-ing" is reached that threatens to become the established and takenfor-granted phenomenon. Understanding becomes pre-understanding so that it is never ingrained (Housset, 2000). The quest for possibilities leads the researcher to problematise reality continuously. Understanding is possible through the dialectic between the tradition and the questioning researcher (the appreciation here of positive dimensions of the prior context resonates with Laclau and Mouffe, 2001, see Gallhofer and Haslam, 2017). Prejudice is only of substantive value when there is the possibility to evaluate it and revolutionize or radically transform it.

Owing to the act of suspension of the prejudice (which does not cancel it but places it on hold), the "Be-ing" (which is a project of "the Being"), makes an utterance against the background of pre-understanding to set forth a second project of "Be-ing". The researcher can project her judgmental capacities on the objects of knowledge relatively freely and understanding springs forth as the phenomenon becomes unveiled. The researcher in this case is not proving her understandings as a concern for proof is not directing her investigation. Findings do not consecrate pre-understanding and prejudices (Heidegger, 1986; Chabrak, 2005).

"Like travellers, we return home with new experiences. Even if we emigrate and never return, we still can never wholly forget" (Gadamer, 1996).

A return to tradition, to prejudice, is inevitable after the first tentative move towards a new project of understanding. Once the act of epoche (suspension) is suspended, a critical and 
evaluating enterprise begins to liberate the researcher from unreflective moments, inherited from tradition, which prevent any understanding. Gadamer, a disciple of Heidegger, notes that the mistake of historicism and objectivism is to try to reduce or even destroy, as distinct from appreciating, the prejudices. Everyone in the world has prejudices or prejudicial interest, by which tacit power directs the mind of the observer towards the solution of problems. The aim of objectivism is to ostensibly shut off from ourselves all presuppositions. Those prejudices "constitute our common life-world from which is enabled the whole process by which scientific knowledge emerges and grows" (Lavoie, 1987, p. 586):

Does understanding in the human sciences understand itself correctly when it relegates the whole of its own historicality to the position of prejudices from which we must free ourselves? Or does 'unprejudiced scholarship' share more than it realizes with that naïve openness and reflection in which traditions live and the past is present...If we disregard ourselves in this way, we have no historical horizon (Gadamer, 1996, p.327).

Understanding is possible through a permanent and never-ending questioning of one's present, and the application of the meaning discovered for one's situation. Understanding is the art of emptying our full cups by enabling tradition to become experience, and of remaining open to the quest for truth. Tradition should never be reified as something simply given (Bernstein, 1982). It should be evaluated and even radically changed.

Researchers here inspired by the focal phenomenon may realize the gap between how they understand accounting through traditional thinking and the imperatives for a break with corporate and problematic hegemonic capture to render, for instance, more social accountability. They become aware of their role in preserving economic capital and financial 
'narratives' legitimating the interests of capital and a problematic socio-political order. They become conscious of their doxic submission to a certain capitalistic and problematic sociopolitical order. They can appreciate how accounting income, in its current form, encourages their tendency to accept human capital exploitation and natural capital depletion alongside their disagreeing with any attempt to restore justice (Cooper et al., 2010). Such discovery carries the potential to initiate a new departure for accounting research and practice. Accounting could encompass the political action to provoke social change towards inclusiveness and sustainability by ensuring information to raise a new conception of accountability and by playing an educational role to help citizens address crucial issues. At the same time our approach here suggests the need for a critical reflexivity and constant questioning of beings as they emerge and become influential. And very key here is Heidegger's reflection on what can be understood in terms of a responsibility to otherness that somehow ought to balance the responsibility to act.

Accounting, in its currently dominant manifestation, tells more than an impoverished economic fable about corporate performance. For Merino (1993), quoting Dewey and Tufts $(1908,1922)$, by encouraging the false conclusion that "monetary gain should be the object of all action", accounting through the "artefact" profit tends to create incentives for extractive logics, exploitation, dubious management practices, discord and social as well as environmental disasters. Today, the IASB's promotion of accounting gives emphasis to its serving of investors in relation to the construct of shareholder value maximization. In any case, the emphasis and the broader mix of interests to which it relates (see Tinker, 1985; Gallhofer and Haslam, 2007) betrays a narrow and problematic orientation. As a technology that in some ways attempts to make market control possible over organizations and subsequently all human life today, accounting is questionable. If the notion of accounting for human rights 
(Cooper et al., 2010; Gallhofer et al., 2011; McPhail and McKernan, 2011; McPhail and Ferguson, 2016), inclusiveness and sustainability is desired, a radically different form of accounting should be developed. We can here see that the implications for accounting research extend beyond the academic discourse and arena to the wider arenas of accounting's mobilization.

In summary, our contribution here, drawing on insights from Heidegger and other phenomenologists, is manifold. We emphasise the importance of recognising the validity and value of driven research that is constantly challenging - initially especially influential phenomena ossified as tradition - and in regard to being attentive to uncovering possibilities through a deep questioning as to the meaning of accounting and its role. At the same time, we endorse a deep reflexivity that seeks to problematize the mind-set of technical control, that sees the valuable in the existing and that has a heightened sense of responsibility to the other. This implies a deep concern to arrive at authentic understanding in the quest for authenticity being aware of prejudice and seeking to be open. These dimensions come together in notions such as seeking a disruptive kind of truth, whereby new possibilities of meaning are revealed, albeit meanings are always acknowledged as partial. Overall there is a mixing or balancing of the politico-ethical responsibility to act with the responsibility to otherness. And the implication of the insights is the advocacy of a cautious pragmatism in an emancipatory approach to the accounting phenomenon.

Crucial moments are when researchers can, as it were, virtually bracket tradition (as Husserl puts it), listen to the phenomenon and potentially adjust their understanding. An approach based on phenomenology of the Dasein in the quest for the "being" (Heidegger, 1986) makes new understandings of accounting and its role possible. Heidegger's philosophical writings add 
a number of insights from a critical perspective. While recognizing an indispensable need in our context for calculative thought and technical control, in research and in practice, Heidegger encourages a basic questioning that is of relevance not least in relation to global and ecological issues - it can be translated as a heightened responsibility to the other (White, 1991). ${ }^{6}$ Heidegger encourages reflexivity (a reflexivity that is also attentive to the value of that existing) and caution while being open to new possibilities (Kolb, 1986). No one can be spared the weight of the world. But from driven activity two types of researchers are born. The first is "narcissistic" and merely prolongs and backs up her knowledge at the expense of understanding. The researcher deploys a calculative technical control approach that might reflect an un-thought practice, serving an empty subjectivity (Heidegger, 1966; Kolb, 1986, p. 120). The researcher here is unable to listen, to see and to adjust what he or she unconsciously internalizes via affiliation to dominant disciplines. Through accounting standards, numbers and concepts, the researcher reinforces objective structures of the system, whether affiliated to neo-classical economics or to alternative, ostensibly critical forms. The second is concerned with accounting, the phenomenon, and its impact on our society. The researcher is aware that 'being' can be seized in a long journey of revealing and concealing of "be-ings". New projects of "be-ings" are raised but they are never solidified and stabilized. They are submitted to the continuous scrutiny of experience and transformed in the endless path towards the "being".

\footnotetext{
${ }^{6}$ Heidegger's appreciation of contingency and of how the history of thought can be understood vis-à-vis co-ordinates set out by Plato, which encouraged control thinking, helps us question the mindset of technical control.
} 


\section{References}

Ahrens, T., Becker, A., Burns, J., Chapman, C. S., Granlund, M., Habersam M., Hansen, A., Khalifa, R., Malmig, T., Mennicken, A., Mikes, A., Panozzo, F., Piber, M., Quattrone, P., and Scheytt, T. (2008). The future of interpretive accounting research - a polyphonic debate. Critical Perspectives on Accounting, 19(6), 840-66.

Arrington, C. E. (2004). Rhetoric and the radically chic: how arguments about academic accounting fall off the runway. Critical Perspectives on Accounting, 15(2), 249-53.

Arrington, C. E. and Francis, J. R. (1989). Letting the chat out of the bag: deconstruction, privilege and accounting research. Accounting, Organizations \& Society, 14, 1-28.

Arrington C. E. and Francis J. R. (1993). Accounting as a Human Practice: The Appeal of Other Voices. Accounting, Organizations \& Society, 18(2/3), 105-6.

Arrington, C.E. and Schweiker, W. (1992). The Rhetoric and Rationality of Accounting Research, Accounting, Organizations \& Society, 17(6), 511-33.

Baker C. and Bettner M. S. (1997). Interpretive and Critical Research in Accounting: a Commentary on its absence from Mainstream Accounting Research. Critical Perspectives on Accounting, 8(4), 293310.

Bernstein, R.J. (1976), The Restructuring of Social and Political Theory, Oxford: Blackwell.

Bernstein, R. J. (1982). From Hermeneutics to Praxis. The Review of Metaphysics, 35(4), 823-45. 
Berenson A. (2004). The number: How the drive for quarterly earnings corrupted Wall Street and corporate America. New York: Random House.

Birkin, F. (1996). The ecological accountant: from the cogito to thinking like a mountain. Critical Perspectives on Accounting, 7(3), 231-57.

Boland, R. (1989). The Coming Hermeneutic Turn in Accounting Research, in Johnson, O. (ed.), Methodology and Accounting Research. Does the Past Have a Future? Urbana-Champaign, IL.: Office of Accounting Research, University of Illinois.

Butler, J., Laclau, E. and Žižek, S. (2000), Eds., Contingency, Hegemony, Universality: Contemporary Dialogues on the Left, London: Verso.

Chabrak, N. (2005). The Politics of Transcendence: Hermeneutic phenomenology and Accounting Policy, Critical Perspectives on Accounting, 16(6), 701-16.

Chabrak, N. (2012). Money Talks: The Language of the Rochester School, Accounting, Auditing \& Accountability Journal, 25(3), 452-85.

Chabrak, N. and Gendron, Y. (2015). Promoting research from the "periphery": Engaging critically with the Global Financial Crisis, Editorial, Critical Perspectives on Accounting, 30(1), 1-8.

Chambers, R. J. (1993). Positive Accounting Theory and the PA Cult. Abacus, 29(1), 1-26.

Christenson, C. (1983). The Methodology of Positive Accounting. The Accounting Review, VIII(1), 122. 
Chua, W.F. (1986a). Theoretical constructions of and by the real. Accounting, Organizations \& Society, $11(6)$, 583-98.

Chua, W.F. (1986b). Radical developments in accounting thought. The Accounting Review, 61(4), 601-32.

Chua, W. F. (1988). Interpretive Sociology and Management Accounting Research - A Critical Review. Accounting, Auditing \& Accountability Journal, 1(2), 59-79.

Chwastiak M. (1999). Deconstructing the Principal-Agent Model: A View from the Bottom. Critical Perspectives on Accounting, 10(4), 425-41.

Clarke, F. L., Craig, R. J., \& Amernic, J. H. (1999). Theatre and Intolerance in Financial Accounting and Research. Critical Perspectives on Accounting, 10(1), 65-88.

Colville, I. (1981). Reconstructing behavioural accounting. Accounting, Organizations \& Society, 6(2), 119-32.

Cooper, C., Coulson, A., \& Taylor, P. (2010). Accounting for Human Rights: Doxic Health and Safety Practices - the accounting lesson from ICL. $6^{\text {th }}$ APIRA Conference Proceedings, Sydney: http://apira2010.econ.usyd.edu.au/conference proceedings/

Cooper D. (1980). Discussion of Towards a Political Economy of Accounting. Accounting, Organizations \& Society, 5(1), 161-6. 
Covaleski, M. A., \& Dirsmith, M. W. (1990). Dialectic tension, double reflexivity and the everyday accounting researcher: on using qualitative methods. Accounting, Organizations \& Society, 15(6), 543-73.

Depraz, N., (1998). La Crise de l'humanité Européenne et la philosophie, Husserl. Paris: Hatier, Series: Profil, textes philosophiques.

Derrida, J., (1995). The gift of death. Chicago \& London: The University of Chicago Press.

Desanti J. T., (1994). Introduction à la phénoménologie. Paris: Gallimard.

Erhard, W., Jensen, M. Zaffron, S. and Granger, K. (2015). Course Materials for: "Being A Leader and The Effective Exercise of Leadership: An Ontological/Phenomenological Model". This course was taught at the Zayed University Convention Center, Dubai, UAE 6 - 8 January and 11 - 13 January, 2015.

Everett, J. (2002). The politics of comprehensive auditing in fields of high outcome and cause uncertainty. Critical Perspectives on Accounting, 14(1/2), 401-62.

Everett, J. (2004). Exploring (false) dualisms for environmental accounting praxis. Critical Perspectives on Accounting, 15(8), 1061-84.

Gadamer, H. G. (1996). Vérité et Méthode: Les grandes lignes d'une herméneutique philosophique. ( $2^{\text {ème }}$ édition). Paris: Editions du Seuil, Collection: L'ordre philosophique. English edition: Truth and Method, translated by Joel Weinsheimer, Continuum International. 
Gaffikin, M. (2009). Being in Accounting for a Time. In Baxter, J., \& Poullaos, C. (eds), Practices, profession and pedagogy in accounting, Essays in honour of Bill Birkett. Sydney: Sydney University Press, chapter 3, 55-78.

Gallhofer, S. and J. Haslam (2003). Accounting and Emancipation: Some Critical Interventions. London and New York: Routledge.

Gallhofer, S. and J. Haslam (2017), Some reflections on the construct of emancipatory accounting: shifting meanings and the possibilities of a new pragmatism, Critical Perspectives on Accounting (available online 10.1016/j.cpa2017.01.004).

Gallhofer, S., J. Haslam and S. van der Walt (2011), Accountability and Transparency in relation to Human Rights: a critical perspective reflecting upon Accounting, Corporate Responsibility and Ways Forward in the context of Globalisation. Critical Perspectives on Accounting, 22(8), 765-80.

Gallhofer, S., J. Haslam and A. Yonekura (2015), Accounting as differentiated universal for emancipatory praxis: accounting delineation and mobilisation for emancipation(s) recognising democracy and difference, Accounting, Auditing \& Accountability Journal, 28(5), 846-74.

Gray, R. (1992). Accounting and environmentalism: an exploration of the challenge of gently accounting for accountability, transparency, and sustainability. Accounting, Organizations \& Society, 17(5), 399-425.

Guignon, C.B. (1999). Introduction. In: Guignon, C.B., Ed. The Cambridge Companion to Heidegger. Cambridge: Cambridge University Press, 1-41. 
Heidegger, M. (1958). Essais et Conférences. Paris: Gallimard, Séries: Tel.

Heidegger, M. (1962). Chemins qui ne mènent nulle part. Paris: Gallimard, Séries: Tel.

Heidegger, M. (1966) Discourse on Thinking. Transl. John Anderson and Hans Freund. New York: Harper and Row.

Heidegger, M. (1977). The Question Concerning Technology and Other Essays. Transl. William Lovitt. New York: Harper and Row.

Heidegger, M. (1986). Etre et Temps. French translation by François Vezin. Paris: Gallimard, Collection: Bibliothèque de Philosophie. English edition: (1962). Being and Time, translated by J.M. Macquarrie \& E. Robinson. Oxford: Blackwell.

Heidegger, M. (1992). Concepts fondamentaux de la métaphysique: Monde-finitude-solitude. Paris: Gallimard, Séries : nrf.

Hines, R. D. (1988). Financial accounting: In communicating reality we construct reality. Accounting, Organizations \& Society, 13(3), 251-61.

Hines, R. D. (1991). The FASB's conceptual framework, financial accounting and the maintenance of the social world. Accounting, Organizations \& Society, 16(4), 313-31.

Hopper, T., \& Powell, A. (1985). Making sense of research in the organisational and social aspects of management accounting: a review of its underlying assumptions. Journal of Management Studies, $22(3), 429-65$. 
Hopper T., Otley D., \& Scapens R. (2001). British management accounting research: whence and whither: opinions and recollections. British Accounting Review, 33, 263-91.

Hopwood, A.G. (2000). Understanding financial accounting practice. Accounting, Organizations \& Society, 25(8), 763-6.

Housset, E., (2000). Husserl et l'Enigme du Monde. Paris: Editions du Seuil, Collection: Points Essais, Séries: Philosophie.

Husserl, E. (1976). La Crise des sciences Européennes et la phénoménologie transcendantale. Paris: Gallimard, Séries: Tel.

Husserl, E. (1992). Méditations Cartésiennes: Introduction à la Phénoménologie. Paris: Librairie philosophique.

Husserl, E. (1998). La philosophie comme science rigoureuse. Paris: PUF, Collection: Epiméthée. English edition: (1965) Philosophy as Rigorous Science, translated by Quentin Lauer. New York: Harper \& Row.

James, O. (2007). Affluenza. London: Vermilion.

Kolb, D. (1986). The Critique of Pure Modernity: Hegel, Heidegger and After. Chicago: The University of Chicago Press.

Kolb, D. (1991). Heidegger at 100, in America. Journal of the History of Ideas, 52(1), 140-51. 
Kompridis, N. (1994). On world disclosure: Heidegger, Habermas and Dewey. Thesis Eleven, 37, 2945.

Kompridis, N. (2006a). Disclosing possibility: the past and future of critical theory. International Journal of Philosophical Studies, 13(3), 325-51.

Kompridis, N. (2006b). Critique and Disclosure: Critical Theory between Past and Future, London: The MIT Press.

Krell, D.F. (1992). Daimon Life: Heidegger and Life-philosophy. Bloomington: Indiana University Press.

Krell, D.F. (2006), Intimations of Mortality, Time, Truth and Finitude in Heidegger's Thinking of Being. Penn State: University Press.

Laclau, E. and C. Mouffe (1987), Post-Marxism without apologies, New Left Review, 166, 79-106.

Laclau, E. and C. Mouffe (2001). Hegemony and Socialist Strategy: Towards a Radical Democratic Politics. $2^{\text {nd }}$ Ed. London: Verso.

Laughlin, R. (1995). Empirical research in accounting: alternative approaches and a case for "middlerange" thinking. Accounting, Auditing \& Accountability Journal, 8(1), 63-87.

Lavoie, D. (1987). The accounting of interpretations and the interpretation of accounts: the communicative function of the "language of business". Accounting, Organizations \& Society, 12(6), $579-604$. 
Lehman, G. (1999). Disclosing new worlds: a role for social and environmental accounting and auditing. Accounting, Organizations \& Society, 24(3), 217-41.

Lehman, G. (2010). Perspectives on accounting, commonalities \& the public sphere. Critical Perspectives on Accounting, 21(8), 724-38.

Lowe, A. (2004). Methodology choices and the construction of facts: some implications from the sociology of scientific knowledge. Critical Perspectives on Accounting, 15(2), 207-31.

Macintosh, N.B. and Shearer, T (2000). The accounting profession today: a poststructuralist critique. Critical Perspectives on Accounting, 11(5), 607-26.

Malpas, J. E. (1992). Donald Davidson and the mirror of meaning: holism, truth, interpretation. Cambridge: Cambridge University Press.

Manicas, P. (1993). Accounting as a human science. Accounting, Organizations \& Society, 18(2/3), 147-61.

McKernan, J. (2007). Objectivity in Accounting. Accounting, Organizations \& Society, 32(1/2), 155-80.

McPhail, K. and J. Ferguson (2016). The Past, the Present and the Future of Accounting for Human Rights. Accounting, Auditing \& Accountability Journal, 29(4), 526-41.

McPhail, K. and J. McKernan (2011), Accounting for Human Rights: an overview and introduction. Critical Perspectives on Accounting, 22(8), 733-37. 
Merleau-Ponty, M., (1999). Phénoménologie de la perception. Paris: Gallimard, Series: Tel. English edition: (1962). Phenomenology of Perception, transl. Colin Smith. New York: The Humanities Press.

Merino, B. (1993). An analysis of the development of accounting knowledge: a pragmatic approach. Accounting, Organizations \& Society, 18(2/3), 163-85.

Mulhall, S. (2005). Routledge philosophy guidebook to Heidegger and Being and Time. Oxford: Routledge.

Neimark M., \& Tinker T. (1986). The social construction of management control systems. Accounting, Organizations \& Society, 11(4-5), 369-95.

Okrent, M. (1988). Heidegger's Pragmatism: Understanding, Being and the Critique of Metaphysics. Ithaca: Cornell University Press.

Parker, L. D. (2008). Interpreting interpretive accounting research. Critical Perspectives on Accounting, 19(6), 909-14.

Parker, L. D., Roffey, B. H. (1997). Methodological themes: Back to the drawing board: revisiting grounded theory and the everyday accountant's and manager's reality. Accounting, Auditing \& Accountability Journal, 10(2), 212-47.

Ravenscroft, S., \& Williams, P. F. (2009), Making imaginary worlds real: The case of expensing employee stock options. Accounting, Organizations \& Society 34(6/7), 770-86. 
Richard, J. (2000). Comptabilité en Russie. In Encyclopédie de comptabilité, contrôle de gestion et audit. Paris: Economica.

Rorty, R. (1991), Essays on Heidegger and Others (Philosophical Papers, Volume 2). Cambridge: Cambridge University Press.

Rorty, R. (1995). Is truth a goal of enquiry? Davidson vs. Wright. The Philosophical Quarterly, 45(180), 279-300.

Rorty, R. (1998). Truth and Progress. Cambridge: Cambridge University Press.

Salanskis, J. M. (1998). Husserl. Paris: Les Belles Lettres, Séries: Figures Du Savoir.

Scapens, R. W. (2008). Seeking the relevance of interpretive research: A contribution to the polyphonic debate. Critical Perspectives on Accounting, 19(6), 915-19.

Shapiro, B. (1997). Objectivity, relativism and truth in external financial reporting: What's really at stake in the disputes. Accounting Organizations \& Society, 22(2), 165-85.

Shearer, T. (2002). Ethics and accountability: from the for-itself to the for-the-other. Accounting Organizations \& Society, 27(6), 541-73.

Sikka, P. (2008). Enterprise culture and accountancy firms: new masters of the universe. Accounting, Auditing \& Accountability Journal, 21(2), 268-95. 
Solomons D. (1991a). Accounting and social change: a neutralist view. Accounting, Organizations \& Society, 16(3), 287-95.

Solomons D. (1991b). A rejoinder. Accounting, Organizations \& Society, 16(3), 311-12.

Spence C. (2009). Social accounting's emancipatory potential: A Gramscian critique. Critical Perspectives on Accounting, 20(2), 205-27.

Thomson, I. (2011), Heidegger, Art and Postmodernity. Cambridge: Cambridge University Press.

Tinker, T. (1980). Towards a Political Economy of Accounting: An Empirical Illustration of the Cambridge Controversies. Accounting, Organizations \& Society, 5(1), 147-60.

Tinker, T. (1985). Paper Prophets: a social critique of accounting. New York: Praeger Special Studies.

Tinker, T. (1988). Panglossian Accounting Theories: The Science of Apologising in Style. Accounting, Organizations \& Society, 13(2), 165-89.

Tinker, T. (1991). The Accountant as Partisan. Accounting, Organizations \& Society, 16(3), 297-310.

Tinker, T. (1999). The Hegelian Logic of Critical Research: Understanding Professor Yoshinori Shiozawa. Accounting, Auditing \& Accountability Journal, 12(1), 39-46.

Tinker, T. and Carter, C. (2003). Spectres of accounting: contradictions or conflicts of interest? Organization, 10(3), 577-82. 
Tinker, T, Merino, B. D. and Neimark, M. D. (1982). The Normative Origins of Positive Theories: Ideology and Accounting Thought. Accounting, Organizations and Society, 7(2), 167-200.

Tinker, T. and Neimark M. (1987). The Role of Annual Reports in Gender and Class Contradictions at General Motors 1917-1976. Accounting, Organizations \& Society, 12(1), 71-88.

Tomkins, C. and Groves, R. (1983). The everyday accountant and researching his reality. Accounting, Organizations \& Society, 8(4), 361-74.

Varela, F.J., Thompson, E., Rosch, E. (1991). The Embodied Mind: Cognitive Science and Human Experience. Cambridge: The MIT Press.

Ward, J.F. (1995). Heidegger's Political Thinking. Amherst: University of Massachusetts Press.

White, S.K. (1991). Political Theory and Postmodernism. Cambridge: Cambridge University Press.

Williams, P. F. (2004). You reap what you sow: the ethical discourse of professional accounting. Critical Perspectives on Accounting, 15(6-7), 995-1001.

Williams, P. F. (2009). Reshaping accounting research: living in the world in which we live. Accounting Forum, 33(4), 274-79.

Willmott, H. C. (1983). Paradigms for accounting research: critical reflections on Tomkins and Groves' "everyday accountant and researching his reality". Accounting, Organizations \& Society, 8(44), 389-405. 